\title{
Pott's puffy tumour: an unforgettable complication of frontal sinusitis
}

\author{
Stephen P Williams, Mark D Wilkie
}

Department of Otolaryngology, University Hospital Aintree, Liverpool, UK

\section{Correspondence to} Mr Stephen Patrick Williams, spwilliams@doctors.org.uk

Accepted 12 November 2014

CrossMark

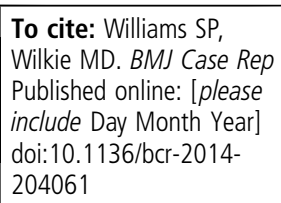

\section{DESCRIPTION}

First described by Sir Percival Pott in 1768, Pott's puffy tumour is a subperiosteal abscess of the frontal bone associated with underlying frontal osteomyelitis. It occurs most frequently as an adverse sequelae of head trauma but can also arise in the setting of frontal sinusitis, as a postoperative complication following craniotomy, or from the spread of infection from adjacent sites, such as dental sepsis. ${ }^{1}$

Since the advent and widespread prescription of antibiotic therapy, Pott's puffy tumour has become a rare entity, largely confined to individual case reports ${ }^{23}$ or small case series. ${ }^{1}$

We report the case of a 63 -year-old man who presented with a 2-week progressive history of a forehead swelling with frontal and retro-orbital pain. Notably, he had a background of chronic rhinosinusitis with nasal polyposis, treated previously with endoscopic sinus surgery and polypectomy some 4 years prior, and described an exacerbation of his sinonasal symptoms over the proceeding weeks.

On examination a large, fluctuant swelling was seen protruding dramatically from the frontal region (figure 1). CT scanning revealed pansinusitis with erosion and fibrillation of the frontal bone in

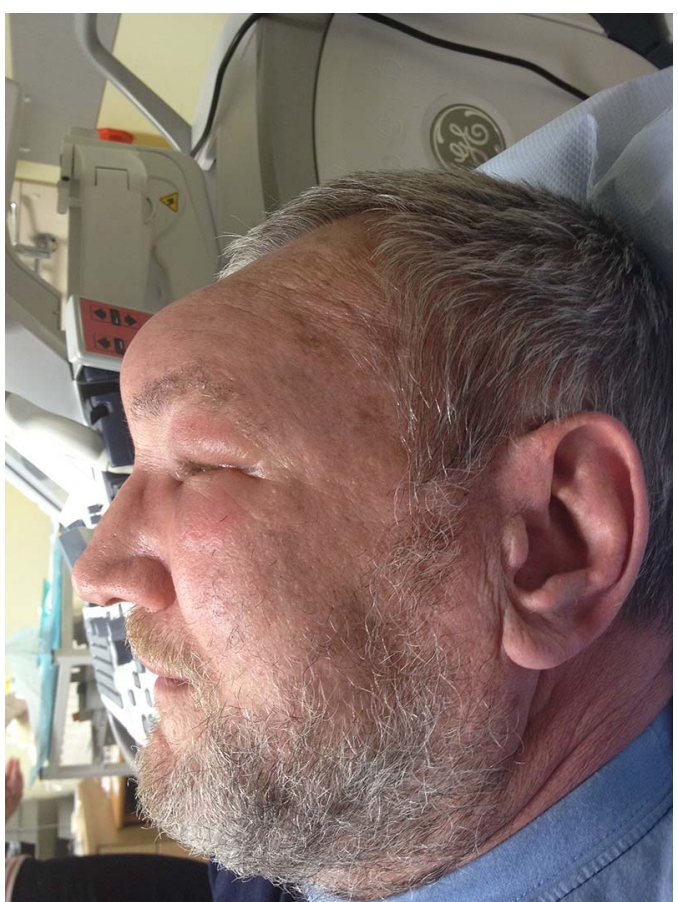

Figure 1 Clinical image, taken from the patient's left side, showing a large swelling protruding dramatically from the frontal region. The patient concerned has given written permission for the presentation here of both his case and this image. keeping with osteomyelitis (figures 2 and 3). An $11 \mathrm{~mm}$ defect in the outer table the left frontal sinus with overlying subcutaneous collection was noted on the corresponding MRI.

External drainage of the abscess was performed under ultrasonic guidance and culture revealed profuse growth of Streptococcus milleri. Following an extended course of treatment with coamoxiclav, the patient underwent definitive revision endoscopic surgery.

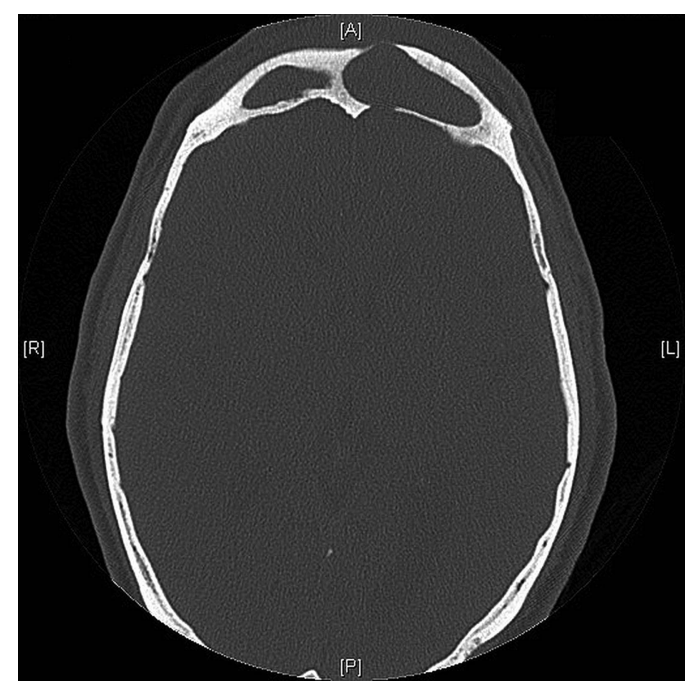

Figure 2 CT images, axial and sagittal slices, respectively, showing pansunusitis with extensive osteomyelitic erosion of the frontal bone.

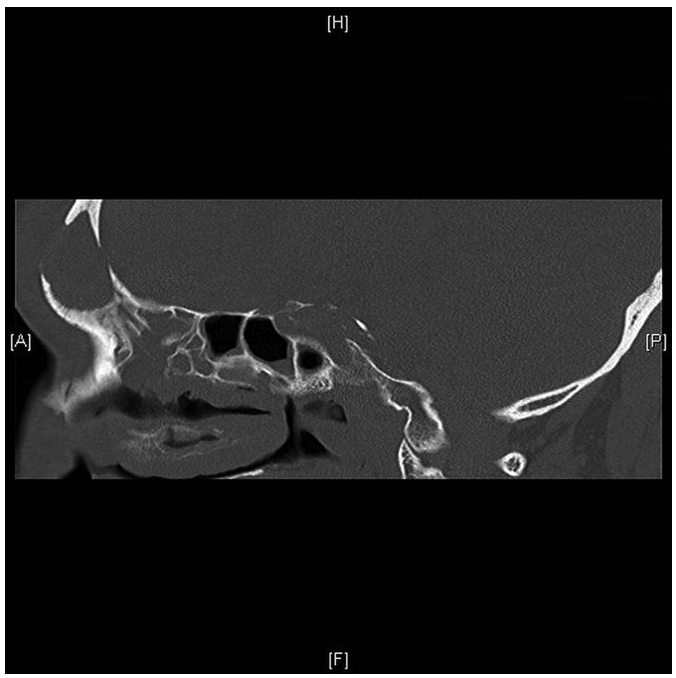

Figure 3 CT images, axial and sagittal slices, respectively, showing pansunusitis with extensive osteomyelitic erosion of the frontal bone. 
Contributors SPW was involved in the conception, planning, drafting and revision of the work. MDW was involved in the conception, planning and revision of the work.

Competing interests None.

Patient consent Obtained.

Provenance and peer review Not commissioned; externally peer reviewed.

\section{REFERENCES}

1 Akiyama K, Karaki M, Mori N. Evaluation of adult Pott's puffy tumor: our five cases and 27 literature cases. Laryngoscope 2012;122:2382-8.

2 Masterson L, Leong P. Pott's puffy tumour: a forgotten complication of frontal sinus disease. Oral Maxillofac Surg 2009;13:115-17.

3 Kombogiorgas D, Solanki GA. The Pott puffy tumor revisited: neurosurgical implications of this unforgotten entity. Case report and review of the literature. J Neurosurg 2006;105(2 Suppl):143-9.

Copyright 2014 BMJ Publishing Group. All rights reserved. For permission to reuse any of this content visit

http://group.bmj.com/group/rights-licensing/permissions.

BMJ Case Report Fellows may re-use this article for personal use and teaching without any further permission.

Become a Fellow of BMJ Case Reports today and you can:

- Submit as many cases as you like

- Enjoy fast sympathetic peer review and rapid publication of accepted articles

- Access all the published articles

- Re-use any of the published material for personal use and teaching without further permission

For information on Institutional Fellowships contact consortiasales@bmjgroup.com

Visit casereports.bmj.com for more articles like this and to become a Fellow 